\title{
PENGUATAN KEBIJAKAN PEMERINTAH \\ DAERAH DAN IMPLEMENTASI \\ OTONOMI PENDIDIKAN
}

\author{
Saepudin Mashuri
}

STAIN Datokarama Palu, Jl. Diponegoro 23 Palu

e-mail: saepudinmashuri@yahoo.co.id

\section{Abstract}

In line with regional authonomy, an authonomy in education through the concept of decentralisation has become a national agenda. In effect, this requires serious attention from the local government. In this era, local government, which has a strong political will to implement an authonomy in education, will be able to improve the quality of education independently. This, in turn, will support local development which is relevant with local needs and potentials. Otherwise, the local government, that is not concerned with this issue, will be reluctant in improving the quality of education. As a consequence, they are not able to support local development towards establishing well-educated society.

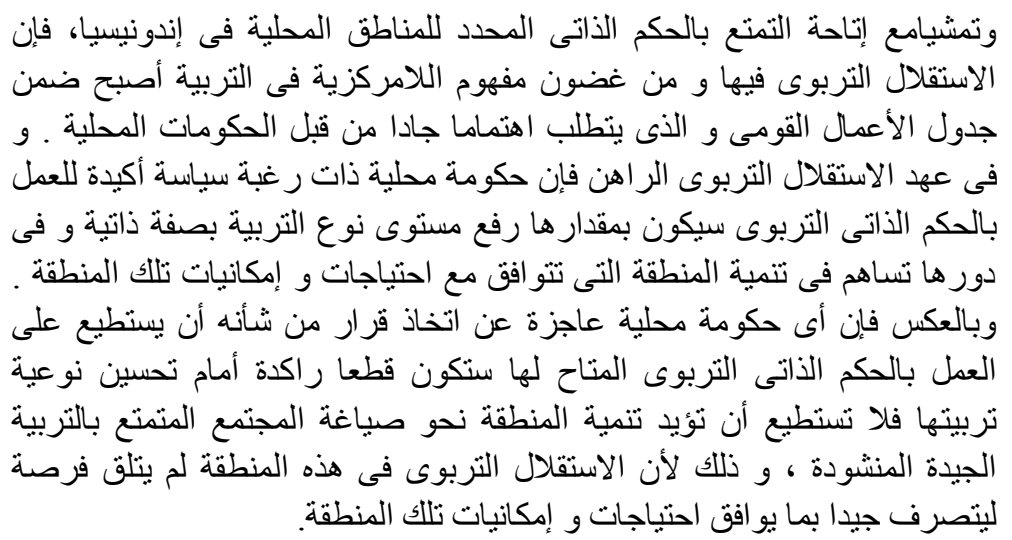

Kata Kunci: kebijakan daerah, Pemerintah Daerah, potensi daerah, otonomi pendidikan, desentralisasi pendidikan 


\section{PENDAHULUAN}

Pemberlakuan Undang-Undang Nomor 23 Tahun 1999 tentang Otonomi Daerah mengisyaratkan kepada seluruh rakyat Indonesia tentang peluang dan kemungkinan pengembangan daerah di berbagai aspek kehidupan secara mandiri sesuai dengan aspirasi, kebutuhan, dan kesiapan pemerintahannya. Salah satu aspek otonomi daerah yang memungkinkan untuk dikelola oleh Pemerintah Daerah dengan mempertimbangkan kesiapan dan kebutuhan lokal adalah bidang pendidikan. Dengan lahirnya undang-undang tersebut, menuntut adanya perubahan paradigma dalam pelaksanaan pendidikan dari yang bersifat sentralistik menuju desentralistik (2006:1). Otonomi pendidikan, kemudian menjadi gerakan pembaruan dunia pendidikan yang memiliki kedudukan strategis dan menjadi harapan baru bagi dunia pendidikan nasional Indonesia dalam mensukseskan tujuan dan cita-cita pembangunan, khususnya dalam upaya meningkatkan kualitas pendidikan masyarakat di daerah sebagai langkah pencerdasan kehidupan bangsa.

Otonomi pendidikan melalui gerakan desentralisasinya, menurut pandangan Tilaar (2002:1), adalah menjadi suatu keharusan untuk segera diimplementasikan dalam sistem bernegara sebagai bentuk pertanggungjawaban Pemerintah dalam membangun masyarakat yang demokratis, masyarakat berprestasi dan peningkatan daya saing bangsa. Jika pandangan Tilaar tersebut diterjemahkan dalam konteks kedaerahan, otonomi pendidikan harus dapat mengakomudir secara fleksibel berbagai kebutuhan masyarakat di daerah, mampu menciptakan masyarakat lokal yang berprestasi, dan mampu meraih kemajuan daerah setempat.

Sehubungan dengan hal tersebut, otonomi pendidikan pada dasarnya adalah upaya Pemerintah Pusat untuk memberdayakan daerah melalui pemberian kewenangan penuh kepada daerah untuk menyelenggarakan pendidikan bagi masyarakatnya sesuai dengan kekhasan, kesanggupan, dan kebutuhan daerah. Alasannya ialah Pemerintah Daerahlah yang lebih mengetahui segala sesuatu yang menjadi kebutuhan pembangunan di wilayahnya. Dalam konteks inilah sangat diperlukan perangkat hukum dan kebijakan yang mampu memberikan penguatan dan mengaspirasi segala kepentingan daerah dalam menyelenggarakan otonomi pendidikan. 
Bila berbicara tentang kualitas pendidikan nasional, akan ada hubungan yang erat dengan perputaran rantai kualitas sistem pendidikan yang ada di daerah sebab pencapaian kualitas pendidikan di daerah menjadi miniatur kualitas pendidikan nasional. Barangkali dari paradigma tersebu maka prestasi pendidikan nasional Indonesia yang jauh tertinggal dari negara-negara Asia lainnya, seperti; Korea Selatan, Singapura, Jepang, dan Malaysia, tidak dapat dipisahkan dari mata rantai kualitas pendidikan daerah dalam kerangka otonomi pendidikan yang sedang bergulir dewasa ini. Apalagi sekolah yang dijadikan sampel untuk mengukur kualitas itu berada di daerah sehingga wajarlah jika kualitas pendidikan nasional pada tingkat siswa sekolah dasar dikatakan sangat rendah.

Lebih jauh lagi, t laporan Bank Dunia melalui studi IEA (International Association for the Evaluation Achievement) menyimpulkan bahwa keterampilan membaca siswa kelas IV SD di Indonesia berada pada peringkat terendah dalam skala internasional. Anak-anak Indonesia ternyata hanya mampu menguasai 30\% dari materi bacaan. Mereka sulit sekali menjawab soal-soal berbentuk uraian yang memerlukan penalaran. Indikator lain yang menunjukkan betapa rendahnya mutu pendidikan di Indonesia dapat dilihat dari data UNESCO tentang peringkat indeks pembangunan manusia (Human Development Index), yaitu komposisi dari peringkat pencapaian pendidikan, kesehatan, dan penghasilan per kepala yang menunjukkan bahwa indeks pembangunan manusia Indonesia semakin menurun dai tahun ke tahun (www.acehforum.or.id/reformulsi-otonomipendidikan).

Dewasa ini, pendidikan di Indonesia mengalami dua masalah besar sekaligus, yaitu persoalan internal dan eksternal. Secara internal, dalam sistem pendidikan Indonesia sedang diadakan berbagai penataan dan restrukturisasi strategi pengembangan yang lebih tepat, akurat, dan ekseleratif. Sedangkan secara eksternal berbagai tantangan dan peluang melalui bidang pendidikan menunggu hasil peningkatan mutu pendidikan yang harus bersaing secara kompetitif dengan negara lain di dunia global.

Berdasarkan hal tersebut, tidak berlebihan, jika dikatakan bahwa dunia pendidikan nasional Indonesia diperhadapkan pada tantangan global yang sangat kompleks, di mana tantangan ini menuntut penataan semua aspek kependidikan secara profesional agar mampu 
melahirkan output pendidikan yang berkualitas global. Salah satu upaya yang telah ditempuh oleh Pemerintah melalui Badan Standarisasi Pendidikan Nasional (BSPN) adalah menetapkan kebijakan tentang Standar Nasional Pendidikan yang disebut dengan Standar Kompetensi Lulusan (SKL) yang mendekati-jika tidak ingin dikatakan sama dengan-standar pendidikan global dari beberapa negara di dunia.

Tulisan ini berusaha mendeskripsikan kepada kita sebagai pelaksana dan pemerhati dunia pendidikan di Indonesia tentang pentingnya penguatan kebijakan daerah yang dapat memberikan dukungan terhadap implementasi otonomi pendidikan, dengan harapan dapat memberikan kerangka pemahaman awal menuju pencapaian kajian otonomi pendidikan yang lebih mendalam.

\section{KEBIJAKAN PEMERINTAH DAERAH DAN IMPLEMENTASI OTONOMI PENDIDIKAN}

Hembusan angin reformasi sejak 1998 telah memberikan suasana segar bagi masyarakat Indonesia untuk menata kembali sistem bernegara dalam berbagai dimensi kehidupan. Millieu inilah yang memberikan inspirasi, sehingga lahirlah nya otonomi daerah yang pelaksanaannya meliputi segala kewenangan. Hal itu telah tercantum dalam Undang-Undang Nomor 22 tahun 1999 tentang kewenangan penuh daerah yang dirumuskan pada Pasal 7 ayat 1, yaitu kewenangan daerah mencakup dalam seluruh bidang pemerintahan, kecuali dalam kewenangan potitik luar negeri, pertahanan, keamanan, keadilan, moneter, fiskal, dan agama (2001:15).

Seiring dengan gaung otonomi daerah maka otonomi pendidikan melalui konsep desentralisasi pendidikannya menjadi agenda nasional yang menuntut perhatian yang serius dari Pemerintah Daerah. Kenyataan ini dibuktikan dengan lahirnya beberapa kebijakan Pemerintah yang sangat signifikan terhadap implementasi otonomi pendidikan, antara lain: Undang-Undang RI Nomor 22 tahun 1999 tentang Otonomi Daerah yang memuat tentang desentralisasi pendidikan atau otonomi pendidikan, Undang-Undang Nomor 20 tahun 3003 tentang Sisdiknas, Undang-Undang Nomor 14 thun 2005 tentang Guru dan Dosen, dan Peraturan Pemerintah Nomor 12 tahun 2005 tentang Standar Nasional Pendidikan (2006: v-viii). 
Dewasa ini, menjadi hal yang paling disayangkan bersama, jika banyak praktisi pendidikan yang belum mengerti hakekat implementasi dari konsep otonomisasi dan desentralisasi pendidikan yang sedang bergulir. Secara kebahasaan, otonomi diartikan sebagai satu keadaan yang independen, bebas, atau tidak terikat. Dalam konteks pendidikan, otonomi itu dapat dikaitkan dengan kebebasan akademik, di mana lembaga pendidikan bebas mengelola pendidikannya sendiri sesuai dengan tujuan pendidikan yang ingin dicapainya ( www. Com/SMFSUI, 2001).

Jika ditilik ke belakang, sentralisasi pengelolaan pendidikan nasional selama Orde Baru ternyata telah menempatkan Indonesia sebagai posisi negara yang tertinggal jauh dibandingkan negara-negara di dunia. Hal ini tercermin dalam laporan United National Development Program (UNDP), yang memposisikan Indonesia pada peringkat 110 dari 173 negara, jauh di bawah Malaysia (peringkat 55), Thailand (peringkat 70), Filipina (peringkat 77), Cina (peringkat 96), dan Vietnam (peringkat 109). Temuan ini telah mendorong lahirnya semangat dan visi baru yang lebih demokratik dan desentralistik dalam pengelolaan pendidikan, sehingga dapat mengembangkan segala petensi peserta didik sesuai kebutuhan kompentensi yang harapkan setiap pesrta didik dan lingkungan di daerahnya.

Dengan semangat demokratisasi, desentralisasi, dan globalisasin maka dalam Undang-Undang Sisdiknas yang disahkan tanggal 11 Juni 2003, terdapat paling kurang 19 pasal yang mengedepankan kata "Pemerintah" dan "Pemerintah Daerah" yang konotasinya adalah berbagai kebijakan dalam pembangunan pendidikan hendaknya selalu mengawinkan kepentingan nasional dan kepentingan daerah, sehingga kualitas pendidikan yag diharapkan dapat meningkatkan daya saing peserta didik secara efisien dan efektif. Dalam pasal-pasal tersebut juga d iungkapkan mengungkapkan hak dan kewenangan Pemerintah dan Pemerintah Daerah untuk menjamin terselenggaranya pendidikan yang berkualitas dengan regulasi yang dapat mengatur sistem pendidikan nasional dan lokal.

Secara singkat dapat disebutkan, misalnya dalam UndangUndang Sisdiknas Pasal 10 dikatakan bahwa Pemerintah dan Pemerintah Daerah mengatur dan mengawasi proses penyelenggaraan pendidikan sesuai dengan peraturan perundang-undangan yang berlaku. Pada Pasal 34 ayat 2 disebutkan bahwa Pemerintah dan 
Pemerintah Daerah menjamin terselenggaranya wajib belajar minimal jenjang pendidikan dasar tanpa memungut biaya. Pasal 44 ayat 1 menyebutkan bahwa Pemerintah dan Pemerintah Daerah wajib membina dan mengembangkan tenaga kependidikan pada satuan pendidikan yang diselenggarakan oleh Pemerintah dan Pemerintah Daerah. Pada ayat 3 dikatakan bahwa Pemerintah dan Pemerintah Daerah wajib membantu pembinaan dan pengembangan tenaga kependidikan pada satuan pendidikan yang diselenggarakan oleh masyarakat. Untuk mendukung operasionalisasi ketentuan pasal dan ayat di atas, Pemerintah dan Pemerintah Daerah menetapkan anggaran pendidikan minimal 20\%. Aturan ini termuat pada Pasal 49 ayat 1 yang menyebutkan disebutkan bahwa dana pendidikan selain gaji pendidik dan biaya pendidikan kedinasan dialokasikan minimal $20 \%$ dari APBN pada sektor pendidikan dan minimal $20 \%$ dari APBD. Pada ayat 4 dikatakan bahwa dana pendidikan dari Pemerintah kepada Pemerintah Provinsi/Kabupaten/Kota diberikan dalam bentuk hibah sesuai dengan peraturan undang-undang yang berlaku.

Sebenarnya masih banyak pasal yang menjelaskan peranan Pemerintah dan Pemerintah Daerah dalam penyelenggaraan pendidikan, tetapi dari beberapa pasal yang disebutkan di atas dapat memberikan gambaran kepada kita tentang hak dan kewajiban Pemerintah dan Pemerintah Daerah dalam pelaksanaan otonomi pendidikan dalam bingkai Sistem Pendidikan Nasional. Pemberian kewenangan kepada Pemerintah Daerah, sebagaimana termuat dalam Undang-Undang Sisdiknas, diharapkan dapat mengembangkan pendidikan di tingkat lokal secara lebih efektif dengan melibatkan semua unsur Pemerintah Daerah dan masyarakat sesuai dengan jenis kompetensi yang dibutuhkan masing-masing daerah. Atas alasan itulah, dalam Pasal 50 ayat 4 dikatakan bahwa Pemerintah Kabupaten/Kota berkewajiban mengelola satuan pendidikan berbasis keunggulan lokal.

Jika setiap pasal dalam Undang-Undang Sisdiknas tersebut dapat dilaksanakan secara tepat dan konsekuen, berbagai kemelut yang mengitari dunia pendidikan kita selama ini dapat diatasi secara bertahap. Oleh karena itu, untuk mengatasi semua hambatan yang terjadi dalam dunia pendidikan kita saat ini diperlukan memerlukan dukungan dan kerjasama dari semua pihak, yaitu dari Pemerintah sebagai penentu kebijakan, hendaknya melahirkan regulasi yang 
berpihak pada kemajuan proses otonomi pendidikan, dari praktisi pendidikan sebagai pelaksana otonomi pendidikan hendaknya menaati aturan yang berlaku, dan masyarakat sebagai stockholder dan pengguna jasa pendidikan hendaknya cinta dengan output pendidikan lokal.

Di era otonomi pendidikan saat ini, Pemerintah Daerah memiliki kewenangan memberikan penguatan kebijakan untuk mengatur pelaksanaan pendidikan di daerahnya masing-masing secara independen. Kondisi ini, di satu sisi menjadi peluang emas bagi setiap daerah yang mampu menentukan arah pencapaian dan kualitas pendidikannya. Di sisi lain, peluang ini akan menjadi "bumerang" bagi daerah yang tidak mampu melahirkan kebijakan yang berpihak pada kemajuan pelaksanaan otonomi pendidikan di daerahnya. Jika Ketika Pemerintah Daerah memiliki political will yang baik, akan ada peluang yang sangat luas bahwa kemajuan otonomi pendidikan di daerahnya akan tercapai secara optimal. Sebaliknya, Pemerintah Daerah yang tidak memiliki kebijakan yang baik di bidang pendidikan dapat dipastikan daerahnya tidak akan pernah mendapatkan momentum yang konduksif untuk melaksanakan pelaksanaan otonomi pendidikan. Daerah dengan kondisi seperti ini, akan mengalami stagnasi menuju pemberdayaan potensi lokal dan mencetak masyarakat yang terdidik (well-educated people) sesuai dengan sasaran pokok otonomi pendidikan.

Tentu saja konsep di atas tidak mudah untuk dilaksanakan karena Pemerintah Daerah harus memastikan bahwa otonomi pendidikan benar-benar sudah dilaksanakan dengan memantapkan semua elemen dan perangkat daerah yang dapat mendukung implementasi otonomi pendidikan di daerahnya dengan baik. Selain itu, upaya ke arah pelaksanaan otonomi pendidikan sudah harus digalakkan agar dapat mencapai hasil pendidikan yang diharapkan mampu memberikan kontribusi bagi kemajuan pembangunan daerahnya.

Menurut Tri Widodo Utomo, (Kompas Edisi 1 Mei 2003), disebutkan bahwa otonomisasi pendidikan tidak hanya membutuhkan perangkat bantuan materil, tetapi juga dukungan moril dan kontribusi pemikiran dari semua komponen daerah. Oleh karena itu, implementasi otonomi pendidikan harus mendapatkan dukungan dari DPRD, sebab DPRD-lah yang menjadi penentu kebijakan di tingkat 
daerah dalam bingkat otonomi daerah. Malik Fadjar (2005:75) mengungkapkan bahawa otonomi pendidikan yang mengacu pada Undang-Undang Nomor 22 Tahun 1999 dengan tegas menyatakan bahwa jiwa dan semangat otonomi adalah kesatuan masyarakat hukum di daerah untuk mengatur rumah tangganya sendiri. Cakupan masyarakat hukum dalam konateks ini tidak hanya Pemerintah, tetapi juga termasuk pebisnis, organisasi masyarakat, lembaga profesi, bahkan sampai unit Pemerintah terkecil, yaitu rukun warga dan tetangga. Penegasan di atas sejalan dengan Undang-Undang Nomor 22 Tahun 1999 Pasal 14 yang mengatakan bahwa di setiap daerah otonomi memiliki sistem pemerintahan yang terdiri dari DPRD sebagai Badan Legislatif dan Pemerintah Daerah (Pemda) sebagai Badan Eksekutif. Kemudian, dalam pelaksanaan otonomi daerah harus ada bekerjasama secara seimbang agar daerah otonom dapat berfungsi secara efektif dan demokratis bagi pembangunan daerah dengan mengikutsertakan peran warga masyarakat secara menyeluruh.

Dalam bidang pendidikan, DPRD memiliki kewenangan dan peran yang kuat dalam membangun paradigma dan visi pendidikan di setiap daerahnya. Ole karena itu, baik gubernur dan bupati/wali kota maupun badan legislatif di daerah harus memiliki kemitraan yang kokoh agar mampu menelorkan kebijakan-kebijakan yang dapat memberikan penguatan terhadap implementasi otonomi pendidikan sesuai dengan potensi yang dimiliki daerah yang bersangkutan untuk mendukung pencapaian tujuan pembangunan daerah. Lebih dari itu, masyarakat harus mampu memberikan masukan kepada Dewan Daerah atau Dewan Kota secara sistematis dan berkelanjutan untuk menghasilkan kebijakan otonomi pendidikan yang dapat mengakomudir kebutuhan dan melestarikan budaya lokal. Kondisi ini mengisyaratkan kepada semua unsur pimpinan di daerah dan masyarakatnya bahwa kemajuan atau stagnasi pendidikan di era otonomi daerah saat ini sangat bergantung pada kebijakan politik pendidikan yang dihasilkan oleh Dewan Daerah atau Dewan Kota yang melembaga ke dalam DPRD-nya masing-masing.

\section{PERAN LEMBAGA PENDIDIKAN DAERAH DALAM IMPLEMENTASI OTONOMI PENDIDIKAN}

Munculnya otonomi daerah, yang menjadi emberio lahirnya otonomi pendidikan berimplikasi besar pada Pemerintah Daerah untuk menentukan kebutuhan dan arah pendidikan ke depan sesuai dengan 
sumberdaya daerah yang dimilikinya. Oleh karena itu, pada era otonomi daerah saat ini, hendaknya menjadi harapan baru bagi setiap lembaga dan praktisi pendidikan untuk terlibat aktif dalam pengembangan pendidikan daerah. Hal mendasar yang perlu diperhatikan dalam otonomi pendidikan adalah mewujudkan organisasi pendidikan di seluruh kabupaten/kota yang lebih demokratis, transparan, efisien, accountable, dan mendorong peran aktif masyarakat pelaksanaan pendidikan di daerah. Dalam konteks otonomisasi pendidikan ini, pembelajaran di setiap lembaga pendidikan di daerah, hendaknya menempatkan Pemerintah Pusat pada posisi sebagai fasilitator dan bukan sebagai penentu/regulator bagi pendidikan di daerah.

Sesuai dengan semangat awal otonomi pendidikan, yaitu memberikan kesempatan yang seluas-luasnya kepada pihak institusi pendidikan di daerah untuk menentukan kebijakan dan arah pendidikannya yang sesuai dengan kebutuhan lokal dan kemampuan sumberdaya yang tersedia, maka lembaga pendidikan di daerah memiliki peran strategis dalam mendukung keberhasilan implementasi otonomi pendidikan. Berkaitan dengan implementasi otonomi pendidikan, Eko Budiharjo menegaskan bahwa peran lembaga pendidikan sebagai pusat pengetahuan (central of science), teknologi, dan pelestarian nilai budaya lokal menjadi sangat strategis. Hal ini dilakukan dalam rangka mempertegas pelaksanaan otonomi pendidikan yang sedang berjalan di satu sisi dan pemberdayaan segala potensi yang terdapat di daerah di sisi lain.

Alasan mendasar yang dijadikan pijakan bahwa lembaga pendidikan memiliki peran strategis dalam pelaksanaan otonomi pendidikan adalah kebanyakan daerah tingkat I apalagi daerah tingkat II (kabupaten/kota) belum mempunyai SDM yang cukup handal dan potensial untuk mengelola daerahnya secara maksimal. Oleh karena itu, Pemerintah Daerah sudah waktunya untuk memberikan ruang bagi lembaga pendidikan untuk berperan aktif melalui kerjasama yang harmonis dan berkelanjutan dalam mensukseskan implementasi otonomi pendidikan.

Lebih lanjut, Eko Budiharjo mengatakan bahwa ilmuwan dan pakar dari lembaga pendidikan lebih didayagunakan sebagai brain trust or thinker untuk membangun daerahnya dalam bidang pendidikan, tidak hanya sekedar sebagai pemerhati dan kritikus atas 
kebijakan Pemerintah Daerah. Masyarakat akademik segera lebih membuka diri, lebih banyak mendengar opini publik, menunjukkan kiprah yang bersinergi dan bertanggungjawab dalam memecahkan masalah yang muncul dalam implementasi otonomi pendidikan yang dijalankan Pemerintah Daerah. Selain itu, Pemerintah Pusat tidak diperkenankan mencampuri urusan rumah tangga tentang pendidikan di daerah secara dominan, tetapi cukup memberikan panduan dan penguatan kebijakan yang didasarkan atas persetujuan Pemerintah Daerah. Dengan kata lain, keterlibatan Pemerintah Pusat dalam implementasi otonomi pendidikan cukup pada dua aspek, yaitu mutu dan pemerataan pendidikan. Pemerintah Pusat menetapkan standar mutu yang akan dijadikan tolok ukur pencapaian standar minimal kualitas pendidikan di daerah dengan memastikan bahwa pemerataan implemantasi otonomi pendidikan sudah berjalan secara merata di seluruh daerah. Peran Pemerintah Pusat hanya sebagai fasilitator bukan selaku regulator, sebab otonomi pengelolaan pendidikan berada di tingkat daerah, terutama di tingkat lembaga pendidikan (sekolah dan perguruan tinggi).

Peran penting lembaga pendidikan adalah menyediakan pakar pendidikan yang dapat memberikan kontribusi pemikiran secara teoritis-konseptual dan tehnis-aplikatif kepada Pemerintah Daerah mengenai strategi implementasi otonomi pendidikan yang efektif dan efisien menurut kebutuhan dan potensi lokal. Disamping itu, masyarakat akademik juga berperan untuk mengawal penerapan kebijakan-kebijakan daerah tentang pelaksanaan otonomi pendidikan agar tetap relevan dengan kebutuhan dan potensi daerah serta tidak menyimpang dari visi dam misi pembangunan di daerah yang bersangkutan.

Salah satu implementasi riil dari otonomi pendidikan adalah lahirnya Menejemen Berbasis Sekolah (MBS) yang memberikan peluang kepada semua sekolah, baik negeri maupun swasta untuk mengembangkan kekhasan (ciri khusus) dan mendorong kompetensi mutu, sehingga melahirkan lembaga pendidikan daerah yang bermutu (unggul) di berbagai bidang (2008:1.6). Karena itu, secara mendasar, MBS bertujuan memberikan kesempatan pada sekolah dan masyarakat untuk bermitra dalam memberdayakan segala potensinya dan mengatur pendidikan di daerah dengan mempertimbangkan kebutuhan dan kemampuan lokal. Pihak sekolah diberikan kesempatan yang 
seluas-luasnya untuk menentukan kebijakan penyelenggaraan pendidikan sesuai dengan kebutuhan dan kemampuan sekolahnya dengan tetap melibatkan peran aktif masyarakat sebagai mitra kerja pendidikan. Melalui MBS ini diharapkan mampu melahirkan tenaga kerja yang terampil dan kreatif, sehingga output lembaga pendidikan di daerah dapat mengambil peran strategisnya dalam pembangunan daerah di segala bidang kehidupan.

\section{PENUTUP}

Kebijakan tentang otonomi pendidikan merupakan suatu keniscayaan yang harus diimplementasikan secara praktis, bukan hanya hadir sebagai sebuah wacana yang diperdebatkan. Pada tataran riilnya, implemntasi otonomi pendidikan di Indonesia memiliki kekuatan sekaligus kelemahan yang mesti ditatap secara arif oleh semua unsur daerah dan praktisi pendidikan, sebab kebijakan ini telah memberikan konsekuensi logis pada daerah untuk melaksanakan tanggungjawab pendidikan secara otonom. Era reformasi dengan semangat reorientasi yang digaungkannya menjadi momentum yang tepat dalam membangun sistem bernegara, sehingga mampu menjadi inspirator lahirnya otonomi daerah yang mengharuskan kepada seluruh daerah untuk melaksanakan otonomisasi di segala bidang, termasuk desentralisasi pendidikan. Realisasi nyata dari otonomi pendidikan telah melahirkan konsep pengelolaan pendidikan yang berbasiskan kebutuhan dan potensi sekolah dan masyarakat daerah yang dikenal dengan MBS.

Pada era otonomi pendidikan dewasa ini, kualitas pendidikan di daerah sangat bergantung pada motif kebijakan Pemerintah Daerah dan kemampuan Pemerintah Daerah untuk bermitra dengan lembaga pendidikan. Pimpinan daerah harus memiliki keinginan politik (political will) yang baik untuk meningkatkan dan memajukan kualitas pendidikan di daerahnya. Jika tidak, maka otonomi pendidikan akan mengalami stagnasi bagi pembangunan pendidikan daerah yang bekualitas. Pemerintah Daerah yang tidak mampu menelorkan kebijakan-kebijakan yang menguatkan implementasi otonomi pendidikan dapat dipastikan bahwa daerah tersebut akan mengalami kemunduran dalam mecetak masyarakat yang well educated dan otonomi pendidikan tidak akan pernah mendapatkan momentumnya untuk berkembang dengan baik. 
Jurnal Hunafa, Vol. 6, No.3, Desember 2009:347-358

\section{DAFTAR PUSTAKA}

Chan, Sam M dan Tuti T. Sam. 2006. Kebijakan Pendidikan di Era Otonomi Daerah. Jakarta: RajaGrafindo Persada,.

Dewan Perwakilan Rakyat RI. 2001. Undang-Undang Otonomi Daerah Tahun 1999. Bandung: Citra Umbara.

Departemen Agama RI. 2006. Undang-Undang dan Peraturan Pemerintah RI tentang Pendidikan. Jakarta: Dirjen Pendidikan Islam.

Fadjar, Malik. 2005. Holistika Pendidikan. Jakarta: RajaGrafindo Persada.

Search. Com/kunluthfi html-Network, Mempertegas Otonomi Pendidikan.

Tilaar, H.A.R. 2002. Membenahi Pendidikan Nasional. Jakarta: Rineka Cipta.

Umaedi dkk., Menejemen Berbasis Sekolah. Jakarta: Universitas Terbuka.

www.acehforum.or.id/reformasi-otonomi-pendidikan

www. Com/SMFSUI, Senat Mahasiswa Fakultas Satra UI, Hasil Seminar tentang Otonomi Pendidikan Nasional, 2001. 